\title{
Military Regimes and Nigeria’s Economic Development, 1966-1999
}

\section{Oluwaseun Peter* and Oluwaseun Oluwaseun Samue}

Department of History and International Studies, Ekiti State University, Ado Ekiti, Nigeria

\begin{abstract}
This chapter examines the military regimes and their various efforts at developing the economy of Nigeria. Economic development and growth has little or nothing to do with military duty or responsibility in any sovereign state. They are supposed to be specialists in ammunitions and war related strategies. The various military take-overs in Africa during the 1950 s and 1960s changed the political and economic administration of the countries involved. Aside from the civil wars that affected most of these countries, economic recessions also nearly brought them to their knees. Nigeria as a major factor in Africa and West Africa politics as at this period also had her fair share of military dictatorial regimes that gave room for a complete change of administration control and nation building.
\end{abstract}

Keywords: Military; Economic development; Nigeria

\section{Introduction}

The role played by the military in Nigeria developmental process cannot be deserted. The impact of the different administrations on the country's economic life has driven such huge numbers of economic experts to think about the current economic circumstance in the nation as a branch of some military defects. Notwithstanding, some researcher opines that, one noteworthy avocation for past military intercessions in an administration, is the mismanagement of the country's resources by the civilian governments which in turn has led to poor socio-economic conditions of the citizenry. ${ }^{1}$ Consequently, the different bungles by the military administrations that asserted to be "remedial specialists" made it clear that they additionally have an eye on the luxurious way of life which the politicians enjoys. ${ }^{2}$ The main focus of this research is to assess the various roles in which the years of military rule in Nigeria have impacted the economic condition of the Nigerian citizen, taking into consideration their economic policies in a dictatorial rule.

\section{Conceptual clarification}

The comprehension of military administration depends on the execution of the different military organizations Nigeria has experienced. Military suggests "pros in the utilization of ammo with the end goal of fighting". ${ }^{3}$ This, however, clarifies why the different military administrations were authoritarian and brutal in nature. They are prepared personnel for war and they can't comprehend the democratic methods for administration. The sequential record of their association in Nigerian legislative issues is sufficient to give a reasonable picture of what military govern stand for. It is where uniform men that are prepared to secure the state choose to pull back themselves from their pledge of office keeping in mind the end goal to harvest the plentiful economic enrichment of the state. ${ }^{4}$ The military administration is an administration driven by military pioneers. It is by and large viewed as an abnormality of administration and a nullification of political advancement. The military administration is an administration

${ }^{1}$ Adesina RA. Military in Politics: Comprehensive Strategies for Ending Military Rule in Africa Nigeria: Heinemann Educational Books. 1999.

${ }^{2}$ Bamgboye PO. The Military and Socio-Economic Development in Nigeria (19831999) A Critical Appraisal. Mediterranean Journal of Social Sciences, 2014, pp: 2340-2344.

3Uzodinma AO. From Military Rule to Civil Rule: A Political Economy of Gerontocratic Metamorphosis in Nigeria. International Affairs and Global Strategy, 2015, pp: 45-53

${ }^{4}$ Ake C. Democracy and Development in Africa. Ibadan: University Press. 1996. overwhelmed by military pioneers. ${ }^{5}$ This is in accordance with Joseph claim, that it is the point at which the military grow their sleeping quarters' limits to the administration limits. ${ }^{6}$ Elaigwu also contends that the military has turned into a political power challenger in Nigeria's condition, which must be "de-politicized". This is to state that the military is a politicized organization, revealing more in administration than their traditional part in Nigeria.

Economic development is the most intense instrument for decreasing neediness and enhancing the personal satisfaction in developing nations. ${ }^{8}$ Both cross-country research and nation contextual investigations give overpowering confirmation that quick and maintained development is basic to gaining quicker ground towards the Millennium Development Goals - and not only the principal objective of splitting the worldwide extent of individuals living on under $\$ 1$ a day. Economic development, for the most part, comprises of development in the level of economic activity and the auxiliary change of the different areas amid the procedure of economic development. In taking a look at the authentic procedure and appointment of chronicled esteem actualities to those results in the recorded procedure, the need emerges to take a look at the course of human exercises affecting political and economic activities in making a society and building up the modern

${ }^{5}$ Eminue O. Military in Politics. Uyo: Soulmate Press and Publishers. 2006.

${ }^{6}$ Joseph R, R. Democracy and Prebendal Politics in Nigeria: The Rise and Fall of the Second Republic. Ibadan: Spectrum Books Ltd. 1991.

${ }^{7}$ Elaigwu Jl. The Military and State Building: Federal-State Relations in Nigeria's Military Federalism (1996-1976). In: Akinyemi AB et al (eds.) Readings on Federalism. Lagos: NIIA. 1979.

${ }^{8}$ Anyiwe MA, Democracy and Economic Growth: Statistical Evidence from Nigeria 1960-2002. Journal of Applied Science 6 (2), 2006.

Ibid

*Corresponding author: Oluwaseun Peter, Department of History and International Studies, Ekiti State University, Ado Ekiti, Nigeria, Tel +2348034354343; E-mail: seuncorrect@yahoo.com

Received June 13, 2018; Accepted June 20, 2018; Published June 27, 2018

Citation: Peter O, Samue OO (2018) Military Regimes and Nigeria's Economic Development, 1966-1999. Arts Social Sci J 9: 369. doi: 10.4172/21516200.1000369

Copyright: () 2018 Peter O, et al. This is an open-access article distributed under the terms of the Creative Commons Attribution License, which permits unrestricted use, distribution, and reproduction in any medium, provided the original author and source are credited. 
state. ${ }^{10}$ An investigation of authentic process suffices an objective or detailed analysis of the character of the society, the structure of the state, the linkages amongst them and how the models in the linkages advance as an expansion of the bigger world. ${ }^{11}$

\section{Overview of military regimes in Nigeria politics}

As corrective regimes, military governments are similar, but in approach, they differ significantly. ${ }^{12}$ Specifically, some are compassionate, others are draconic and some fall in-between. Intermittently, and for twenty-eight years, the military called the shots in Nigeria's political history; hence as a result, professionalism was relegated, coups gained currency, careers and lives were wasted. Significantly, they became part of the problem; thirty -four years ago, i.e. in 1966, some army majors and other officers killed some civilian politicians and some senior military officers in a coup de tat. In that coup, Sir Abubakar Tafawa-Balewa, the first Prime Minister of Nigeria; Sir Ahmadu Bello, Sardaunan of Sokoto who also happens to be the Premier of Northern Nigeria; Chief Festus Okotie Eboh, the Federal Minister of Finance, and Chief Samuel Akintola, the Premier of Western Region, were brutally killed. ${ }^{13}$ In addition, Brigadier, Zakari Maimalari, Colonels Kur Mohammed and Abogo Lagema lost their lives. Major Chukwuma Kaduna Nzeogwu led the coup, and in his address to the Nation, he stated why they struck. According to him, they intervened to wipe out corruption, nepotism and to elevate Nigeria. Although the first Prime Minister, Abubakar Tafawa Balewa and other top officials were killed, the coup failed. ${ }^{14}$

In Lagos, General Aguiyi Ironsi, the then highest-ranking military officer, quelled the revolt with the help of some other military officers. With the loyal officers and Men of the Nigeria Army, Ironsi routed the coupists, and in Kaduna, Nzeogwu was on one limb. With little or no logistics, a fresh supply was blocked, as both Kano and Lagos, where the coup had failed refused his orders. After several emissaries and assurances, Nzeogwu laid down his arms, went to Lagos and was arrested and detained. Thereafter, Honourable Nwafor Orizu, the Senate president, met with some Ministers and handed power to General Aguiyi Ironsi. Six Months later at around July 1966, there was a countercoup, and in that countercoup, General Ironsi was killed alongside his host Adekunle Fajuyi in Ibadan while Lt-Colonel. Yakubu Gowon, the highest-ranking Northerner, succeeded Ironsi. He ruled for nine years, through the civil war and the oil boom, terminating in $1975 .{ }^{15}$

Young and inexperienced, Gowon relied on the civil servants, and they became very powerful. Permanent secretaries dictated the tune

${ }^{10}$ Lewis WA. Theory of Economic Growth, Tenth Printing, Unwin University Books, London, 1972

${ }^{11}$ Abdulwaheed SA. et al. Dynamics of Government Policies in Nigeria's Economic Development (1960-1979). Journal of Economics and Sustainable Development www.iiste.org ISSN 2222-1700 (Paper) ISSN 2222-2855 (Online) Vol.3, No.11, 2012

${ }^{12}$ Metz HC. Nigeria: A Country Study. Washington: GPO for the Library of Congress 1991. http://countrystudies.us/nigeria/.

${ }^{13}$ Balogun O. The Tragic Years: Nigeria in Crisis 1966-1970, Benin City: Ethiope Publishing Corporation, 1973, p: 94

${ }^{14}$ Udenwa A, Nigeria/Biafra Civil War: My Experience, see also Ola Balogun's Tragic Years, Achebe's There was a country, and Ademoyega's Why we Struck, The story of the first Nigerian coup, Ibadan: Evans publisher, 1981, pp: 102-112.

${ }^{15}$ Araba MA. Let's Separate: The Story of the Nigerian Civil War, Author House Publisher, 1990 see also Aremu JO, Osadola OS, The Organization of African Unity and Its Mediatory Role in the Nigeria Civil War: A Historical Assessment. International Journal of Research, Vol. 5, Issue 15, 2018, pp: 214-238. while ministers and political appointees watched. Awash with petrodollars, Nigeria went on a spending binge beyond her shores. In 1974, Gowon in a national broadcast rescinded his promise to hand-over to the civilians in 1976. This angered some politicians and military officers, and later in July 1975, Gowon was toppled in a bloodless coup. Brigadier Murtala Ramat Mohammed emerged as the new leader. Laced with revolutionary rhetorics, he flushed out deadwood and bad eggs and in the exercise; all sections of the country were affected. With dispatch, Murtala drew up his transition, itemized his priorities and promised a hand over date of 1st October 1979. However, Murtala was murdered in a bloody coup. The ringleader was Lt. Colonel Bukar Sukar Dimka. ${ }^{16}$

The coup was badly motivated and planned; it was, however, an unpopular one. Like Nzeogwu's, Dimka's attempt failed, as Olusegun Obasanjo, a Lt. General and Murtala's second-in-command assumed control. Generally, he stuck to Murtala's transition and kept his vision drive. On October 1, 1979, power was handed over to an elected president, Alhaji Shehu Aliyu Usman Shagari. ${ }^{17}$

For about five years, there was a lull and as the Military retreated to the barracks, politicians had a field day. Tainted by corruption, and political thuggery, politicians provided the excuse and the Military grabbed the chance and bounced back. By December 31,1983, the second Republic fell, ${ }^{18}$ as a coup staged by some senior officers was relatively peaceful, and successful. Heralding the charges, Brigadier Sani Abacha reeled off a litany of woes. According to him, unemployment was high, infrastructure had collapsed, hospitals became "mere consulting clinic". In spite of this, he lamented, politicians lavish in squanderMania and to hold the drift, they sacked the inept government of Shagari. Afterwards, Muhammadu Buhari, a Major- General, became the new leader. ${ }^{19}$

This regime was a two-man affair, Buhari, and Brigadier Tunde Idiagbon, his second in- command, ruled alone, to the chagrin of others; others were sidelined and a crack emerged. Twenty Months later, in 1985 to be precise, they were removed by their colleagues. Again, Abacha brought the bad tidings, citing lack of consultation and insensitivity as reasons why they struck..$^{20}$ Brigadier Ibrahim Babangida, who was then the chief of Army Staff, became the Head of State. With his Machiavellian tactics, Nigeria under his leadership joined the Organisation of Islamic Conference (O.I.C) and restored relations with Israel. For this reason and others, the press descended on him and called him names; human rights, Christian and Muslim groups were unsparing. In addition, the structural Adjustment programme (S.A.P.), an austerity measure he introduced made him unpopular. ${ }^{21}$ Under S.A.P., Nigerians were generally impoverished; in the political realm, politicians were also frustrated over series of banning and shifting of hand over date, politicians were fed up. On August 28 , 1994, due to serious domestic pressures, Babangida reluctantly stepped

${ }^{16}$ Adesina RA. Military in Politics: Comprehensive Strategies for Ending Military Rule in Africa Nigeria: Heinemann Educational Books. 1999

${ }^{17} \mathrm{~T}$. Falola, and Julius Omozuanvbo Ihonvbere. The Rise and Fall of Nigeria's Second Republic, 1979-1983. London: Zed Books, 1985.

${ }^{18}$ Awofeso O. The Military and Politics in Nigeria. Unpublished Monograph. 2002.

${ }^{19}$ Falola T, Julius Omozuanvbo Ihonvbere. The Rise and Fall of Nigeria's Second Republic, 1979-1983. London: Zed Books, 1985.

${ }^{20}$ Kolawole D. Issues in Nigerian government and politics. Ibadan: Dekaal Publishers. 1998.

${ }^{21}$ Soetan SO, Osadola OS, Debt Burden: A Re-Examination of its Effects on Nigeria's Nation Building. Journal for Studies in Management and Planning ISSN 2395-0463 Volume 04 Issue 01, 2018, pp: 43-50. 
aside leaving an Interim National Government (ING) led by Ernest Shonekan. Abacha was the Secretary of Defence, he controlled the armed forces and in the event of death or resignation, the I.N.G. Decree said, the most senior secretary would succeed Shonekan. At that time Abacha fit the bill and from the decree, the I.N.G was vulnerable, and on November 17, 1994, Abacha shoved it aside and ascend the throne. He held on to power and planned to succeed himself. To give his plan legitimacy, he contrived a transition programme asking politicians to partake. ${ }^{22}$

Immediately political associations sprang up, the government teleguided the chosen parties, thus determining who won what position. Geared towards self- succession, Abacha was undecided, but the signs were there. Over these exercises, most politicians, especially the bigguns, saw a hidden agenda and became apathetic to the transition programme. Abacha was on a final climax to succeed himself when he died on June 8, 1998. Two days later, General Abdulsalami Abubakar, the chief of Defence Staff, became the Head of State.

From the foregoing, Nigeria has had seven Military Regimes and has been under the Military rule for twenty-eight years out of the fiftyseven years of her existence as a sovereign and independent Nation. This research, therefore, seeks to critically assess or appraise the Military impact on the economic growth of Nigeria from 1966- 1998.

\section{Military Regimes and Economic Efforts in Nigeria}

It is no doubt a known fact that the Nigeria military has had a viable impact on the economic development of the country within the period they ruled. ${ }^{23}$ The various economic policies were targeted at raising the living standard as well as improving the economic growth of Nigeria. Although the various military regimes were also characterized by corruption and economic wastage, one can't but acknowledge the impact which some of their policies had on the growth and development of the nation economically.

After the civil war, the Federal Military Government moved to revive the six-year development plan initiated in 1962. The First National Development Plan outlined Nigeria's change from a basically agricultural economy to a blended economy in light of agricultural extension and constrained modern development. The government was vigorously engaged with the economy on the grounds that privately created private speculation was not able to produce adequate capital for development. New development plans were initiated in 1970 and $1975,{ }^{24}$ however, the objectives set in every one of the three plans demonstrated uncertainty. While some of these plans are short-range and medium-range plans, others are perspective and rolling plan. Although to an extent, there have been some signs of progress; these attempts have been fraught with difficulties that have emerged from the continued reliance on adopted western models inherited from their former colonial powers. These development models have been rooted in the colonial development plans drawn up during the colonial period..$^{25}$

${ }^{22}$ Bellow UK. Fiscal Policy Implications of Structural Adjustment Program. A paper presented at the First National Biennial Conference of the Faculty of Business Administration, University of Lagos, Lagos, Nigeria, Oct. 26-28, 1987.

${ }^{23}$ Bamgboye PO. The Military and Socio-Economic Development in Nigeria (19831999) A Critical Appraisal. Mediterranean Journal of Social Sciences, 2014. pp: 2340-2344.

${ }^{24}$ Oyewale PO, Osadola OS, Western Development Plans: A Re-Examination O Post-Colonial British West Africa, International Journal of Research, Volume 05 Issue-01, 2018, pp: 784-792.

${ }^{25}$ lbid
By the late 1960s, oil had supplanted cocoa, peanuts, and palm items as the nation's greatest foreign exchange earner. ${ }^{26}$ In 1971, Nigeria- - by then the world's seventh-biggest oil producer - became a member of the Organization of the Petroleum Exporting Countries (OPEC). The emotional ascent in world oil costs in 1974 caused a sudden surge of riches that can be depicted as "dynamic turmoil." Much of the income was proposed for speculation to enhance the economy, yet it additionally impelled expansion and, coming amidst boundless joblessness, underscored disparities in dissemination. In 1975 production fell pointedly because of the sudden abatement in world request, and costs moved downward until the point that late in the year when OPEC mediated to raise costs. Nigeria completely upheld OPEC policies. ${ }^{27}$

In 1972 the government issued an indigenization proclaim, the first of various Nigerian Enterprises Promotion announces, that banned outsiders from putting resources into indicated undertakings and held an interest in specific exchanges to only Nigerians. ${ }^{28}$ At the time, around 70 percent of business firms working in Nigeria were foreignpossessed. In 1975 the federal government purchased 60 percent of the value in the marketing activities of the significant oil organizations in Nigeria, yet full nationalization was dismissed as a method for facilitating its program of indigenization..$^{29}$

Joblessness constituted an undeniably significant issue. ${ }^{30}$ Vast quantities of farm workers, who had gone to urban territories looking for higher wages, stayed in the urban communities regardless of whether they neglected to discover employment, while school graduates and dropouts overwhelmed the labour market at a rate of 600,000 a year in the mid-1970s. ${ }^{31}$ Joblessness achieved its most elevated amounts in the jammed Igbo territories in the east, where the economy still was recouping from the impacts of the war. Gifted workers were hesitant to leave the east looking for work, albeit, in the long run, the deficiency of skilled workers in different parts of the nation started to have its impact in defeating Igbo fears. The perils associated with releasing expansive quantities of officers who had no activity prospects made deactivation of the exorbitant military foundation unwanted. Significant increments in broad daylight segment business guaranteed to retain a portion of the troopers, yet they lack proper training. These economic issues expected a forcing political measurement. To some degree, they reflected an example of the world's economic circumstance, yet the well known creative energy faulted corruption and mismanagement and blamed the Gowon administration dependable.

The regime likewise needed to manage a serious drought that struck the northern states in the vicinity of 1972 and 1974. The drought was the most genuine since that of 1913-14. ${ }^{32}$ The drought that resulted in

${ }^{26}$ Olomola IG. Main trends in African history from earliest times to 1900 . Ibadan: Omolayo Press. 1969

${ }^{27}$ Soetan SO, Osadola OS, Debt Burden: A Re-Examination of its Effects on Nigeria's Nation Building. Journal for Studies in Management and Planning ISSN 2395-0463 Volume 04 Issue 01, 2018, pp: 43-50.

${ }^{28}$ Forrest, Thomas. Politics, Policy, and Capitalist Development in Nigeria, 19701990. Boulder, Colorado: Westview Press, 1992.

${ }^{29} \mathrm{James}$ SC. Nigeria: Background to nationalism. California: University of California Press. 1958.

${ }^{30}$ Nwagbara EN. Industrial relations under structural adjustment programme: a comparative analysis of Nigeria and Ghana. (unpublished Ph. D dissertation submitted to the Graduate School, University of Calabar, Calabar). 2004.

${ }^{31}$ Forrest, Thomas. Politics, Policy, and Capitalist Development in Nigeria, 1970 1990. Boulder, Colorado: Westview Press, 1992.

${ }^{32}$ Dennis LC, John D. Political economy of Africa. London: Longman. 1981. 
famine influenced the Sahel countries toward the west, north, and east much more than Nigeria, however significant quantities of refugees filled Nigeria from Niger. Famine conditions likewise prevailed in a few sections of the north of Nigeria. Over the long haul, in any case, Nigerian agriculture profited from the rise in prices that came about because of crop failures in different parts of the Sahel. In the short run, the drought impacted policy choices about the need of advancing irrigation plans and reforestation. ${ }^{33}$

Murtala Muhammad started a thorough survey of the Third National Development Plan by singling out inflation as the most serious threat to the economy, ${ }^{34}$ he was resolved to lessen the cash supply that had been swollen by government expenditures on public works. Murtala Muhammad likewise declared that his government would empower the quick development of the private sector into territories commanded by public corporations. He reappraised foreign policy, focusing on a "Nigeria first" 35 introduction in accordance with OPEC value rules that was to the impediment of other African nations.

The military regimes of Murtala Muhammad and Obasanjo profited from a vast convergence of oil proceeds that stretched 350 percent in the vicinity of 1973 and 1974, when oil costs rise, until 1979 when it rapidly declined. ${ }^{36}$ Extended revenues permitted gigantic spending that deplorable was foolish and mainly beneficiary to the urban zones. The oil boom was destroyed by a minor withdraw in 1978-79, yet revenues ricocheted back until mid-1981. The development in revenues made possible a speedy rising in pay, especially for the urban professional class. There was a contrasting inflation, particularly in the cost of food, which advanced both industrialization and the advancement of rural creation. Because of the move to food trims, the customary fare workers - peanuts, cotton, cocoa, and palm items - declined to a very large extent and afterward lost its fundamentalism by all methods. Nigeria's exports were wildly commanded by oil. ${ }^{37}$

At the point when, in 1976, the Federal Military Government of Nigeria propelled the Operation 'Feed the Nation' Program (OFN), because of the constant powerlessness of the rural area of the economy to fulfill the food needs of the nation, there was promise for a restoration of enthusiasm for farming. Sadly, following two years of activity, the plan has not accomplished the normal objectives. It is felt that this obvious disappointment of the OFN scheme gets from its authoritative and operational structure which does not appear to contrast particularly from the current bureaucratic agricultural ministry, the disappointment of which prompted the OFN scheme. ${ }^{38}$ As a result, the real peasant farmers, who, the author argues, had sustained the nation's economy before the era of mineral oil in the country, have not been reached by the scheme. A structural change

${ }^{33}$ Ikime O. (ed.). Groundwork of Nigerian History. Ibadan: Heinemann Educational Books for Historical Society of Nigeria, 1980.

${ }^{34}$ Oyewale PO, Osadola OS, Western Development Plans: A Re-Examination O Post-Colonial British West Africa, International Journal of Research, Volume 05 Issue-01, 2018, pp: 784-792.

${ }^{35} \mathrm{Garba} J$. Fractured history: Elite shifts and policy changes in Nigeria. New Jersey: Sunghai Book. 1995.

${ }^{36}$ Agagu A and Ola RF, (Ed). Development Agenda of the Nigerian State, Lord Akure: Keynes Publishing. 2007.

${ }^{37}$ Forrest, Thomas. Politics, Policy, and Capitalist Development in Nigeria, 1970 1990. Boulder, Colorado: Westview Press, 1992. See also Adeyinka AT, Oyewale $\mathrm{PO}$, Osadola OS Continuity and Changes in Palm Oil Production in Ekiti Land IOSR Journal of Humanities and Social Science (IOSR-JHSS). Vol. 22 No. 12 2017, pp: 17-23.

${ }^{38} \mathrm{bid}$ in the OFN scheme is discussed and suggestions for improvement in the programme are proposed through what the author describes as the Selected Farmers' Scheme. Proposals for a massive stepping up of the recruitment, training, deployment, and administration of extension manpower are made, by which means the author hopes Nigeria will achieve sufficiency and self-reliance in food production. ${ }^{39}$

One vital element of the considerable number of approaches aside from Operation Grow More Food is that the projects were extra to the typical projects executed under the ordinary budgetary framework. Thus special funds were allocated for the purpose or where appropriate the funds under the regular budgetary system were increased to reflect the new policy. Prior to the presentation of OFN, State Governments used to import manures specifically from abroad at a high cost because of high harm in light of the fact that charted vessels used to wait for almost half a year before they could get berthing facility. ${ }^{40}$ With the introduction of OFN importation was centralized and special berths were made available for fertilizer ships. Thus, the quantity of fertilizer imported rose from 50,000 tonnes in 1976 to 400,000 tonnes in $1978 .{ }^{41}$ Furthermore, a special unit was set up under the Federal Ministry of Agriculture and Rural Development to be solely responsible for the importation and distribution of fertilizers.

When Green Revolution was initiated in 1979, importation of fertilizers was augmented to $1,000,000$ tonnes by 1981 . Subsequently, the measure was reduced to about 800,000 tonnes. ${ }^{42}$ The subsidy factor was maintained all through the time. Efforts were made to privatize the importation and circulation, but the idea was shelved. With the coming of the Operation Grow More Food, the general policy of importation and subsidy was maintained. Fertilizer is very essential to the programme of the Directorate for Food, Road and Rural Infrastructure. This is probably because the second fertilizer factory has recently been opened and the two factories will provide a substantial quantity of fertilizer needs of the country which will also boost food growth and harvest.

Under the OFN the National Seed Service was formed in 19 states, and more than 2,000 tonnes of improved seeds of various types were dispersed to the farmers. By the time the Green Revolution came into operation, the National Seed Service was producing about 4,000 tonnes of improved seed. ${ }^{43}$ During this period a lot of importance was placed on rice production. With the introduction of Operation Grow More Food, there was no special programme for seed except that the National Seed Service continued to operate under the normal budgetary system. The OFN programme embarked on large-scale multiplication of vegetable seeds through the Horticultural Research Institute and Institute for Agriculture Research for distribution to farmers. Same quantity was also imported from overseas. The Green Revolution and Operation Grow More Food did not emphasize fruit and vegetable production while the Directorate plans to cultivate " 50 million fruit trees and

${ }^{39}$ Larr F. Nigeria's Journalistic Militantism: Putting the Facts in Perspective on How the Press Failed Nigeria Setting the Wrong Agenda and Excessively Attacking Olusegun Obasanjo. Author House Publisher. 2011.

${ }^{40}$ Aleyideino WI. Launching of the Operation Feed the Nation. Ministry of Home Affairs and Information, 1976.

${ }^{41}$ OFN, Annual Report, Secretariat, National Committee of Operation Feed the Nation, 1976.

${ }^{42} \mathrm{OFN}$, Annual Report, Secretariat, National Committee of Operation Feed the Nation, 1976.

${ }^{43}$ Larr F. Nigeria's Journalistic Militantism: Putting the Facts in Perspective on How the Press Failed Nigeria Setting the Wrong Agenda and Excessively Attacking Olusegun Obasanjo. Author House Publisher. 2011. 
massive vegetable seedlings", in order to improve the general health of the people. ${ }^{44}$

Fifty thousand day-old chicks and over 17,000 tonnes of premix were imported in an attempt to increase poultry production under OFN. ${ }^{45}$ During the Green Revolution importation of maize continued and poultry production improved substantially. Plans to increase rabbit production during OFN and Green Revolution did not materialize. The Directorate for Food, Road and Rural Infrastructure, on the other hand, has allocated N10 million for the development of cattle, poultry, piggery, rabbitry, sheep, goats, etc. Furthermore, during the OFN and the Green Revolution canoes, fishing boats, and gears were made available to fishermen at $50 \%$ subsidy. The Directorate plans to produce 50 million fingering and about 180,000 tonnes of fish feed. ${ }^{46}$

Industrialization, which had developed gradually after World War II through the civil war, boomed in the 1970s, regardless of numerous foundation requirements. Development was especially articulated in the production and assembly of consumer goods, including vehicle assembly and the maker of soap and detergents, soft drinks, pharmaceuticals, beer, paint, and building materials. Moreover, there was broad interest in infrastructure from 1975 to 1980 , and the quantity of parastatals - jointly government-and private organizations - multiplied. ${ }^{47}$ The Nigerian Enterprises Promotion decree of 1972 and 1977 further empowered the development of an indigenous working class.

Buhari endeavoured to reestablish open responsibility and to restore a dynamic economy without adjusting the essential power structure of the nation. The military had turned out to be eager with the civilian government. Corruption specifically was wild, and the false election had been excessively self-evident. Since the civilian government head by the NPN couldn't control the circumstance, the military took over. In any case, Buhari's political and economic points were relatively indistinguishable to those of the NPN. ${ }^{48}$

The military administration conducted tribunals to check corruption, and numerous outrages were uncovered. However, the civil service was scrubbed, even though it can't be compared with that of 1975. This time, the military endeavoured to accomplish two points. In the first place, it endeavoured to secure public help by diminishing the level of corruption; second, it showed its sense of duty regarding somberness by trimming the federal budget. As a further endeavour to assemble the nation, Buhari propelled a War Against Indiscipline in spring 1984. This national crusade, which kept going fifteen months, lectured the hard-working attitude, accentuated patriotism, discredited corruption, and advanced natural sanitation. ${ }^{49}$

The fight was a military program for change and gathering that proficient few of its focuses. For all intents and purposes, joblessness was on the rising as the subsidence exacerbated, so discussions about

${ }^{44}$ Aleyideino WI. Launching of the Operation Feed the Nation. Ministry of Home Affairs and Information, 1976.

${ }^{45}$ OFN, Annual Report, Secretariat, National Committee of Operation Feed the Nation, 1976.

${ }^{46}$ OFN, Annual Report, Secretariat, National Committee of Operation Feed the Nation, 1976.

${ }^{47}$ Helen Chapin Metz, ed. Nigeria: A Country Study. Washington: GPO for the Library of Congress, 1991. http://countrystudies.us/nigeria/

${ }^{48}$ Ekeh P, Military Rule, and Damage to the Spirit of the Nigerian Constitution, State University of New York at Buffalo. Urhobo Historical Society, 2010.

${ }^{49}$ Uzodinma AO. From Military Rule to Civil Rule: A Political Economy of Gerontocratic Metamorphosis in Nigeria. International Affairs and Global Strategy, 45-53. 2015. buckling down appeared to be strange. The enthusiasm to Nigerian patriotism had the negative effect of limiting the flexibility of the organization in overall exchanges over the obligation. The campaign was actualized indiscreetly; a couple of individuals were executed or given long remedial office terms while others were permitted off on the off chance that they were very much associated. ${ }^{50}$ Ecological sanitation suggested that the state capitals must be cleaned up, and the basic target was the minor bourgeoisie that pressed a living out of offering administrations or retailing things on a little scale. Their "unlawful structures" advertise backs off and workshops along the lanes - were destroyed, and in all cases abhor happened among the little vendors, repairmen, and others in the autonomously utilized administration part.

Towards the finish of the Shagari's administration in 1983, the unpaid short-term trade debts of Nigeria of about \$4billion has increased while joblessness was at its pinnacle causing a genuine adjust of payment shortfall. This economic condition made the Shagari administration to seek for the International Monetary Fund (IMF) for three years expanded facility loan of $\$ 2.3$ billion. ${ }^{51}$ The failure to meet the seventeen conditions expressed by the international financial institution for such a credit dragged its transactions through Buhari administration and furthermore to Babangida's administration of 1985 when the debate was inevitably dismissed. This dismissal close by the awful economic emergency confronting the nation amid this administration provoked the Babangida organization to present the Economic recuperation program in July $1986 .{ }^{52}$

These economic crisis involved the change of the economy from one subject to horticulture to one intensely reliant on oil; broad bends and irregular characteristics in the economy; substantial reliance on oil and imported data sources which rendered it profoundly defenseless against outer stuns; forcefully declining outside trade saves; a to a great extent 'overvalued' naira; stunning outer obligation; disturbing extents of joblessness; balance of payments crisis; and the fall of oil prices. ${ }^{53}$ The Nigerian SAP was intended to fit the standard IMF-World Bank basic change bundle. It was intended to viably modify and rebuild the utilization and generation examples of the Nigerian economy and to wipe out value mutilations and overwhelming reliance on the fare of raw petroleum and imports of buyer and maker products. It is a program which joins a nexus of measures to advance the economic effectiveness and longhaul development, with adjustment approaches intended to reestablish harmony of installments balance and value solidness. ${ }^{54}$

The overall aim is to totally revamp the Nigerian economy. Indeed, as Obadan and Ekuehare ${ }^{55}$ noted, Nigeria's SAP is planned to discourage

${ }^{50}$ Bamgboye PO (2014, November). The Military and Socio-Economic Development in Nigeria (1983-1999) A Critical Appraisal. Mediterranean Journal of Social Sciences, 2340-2344.

${ }^{51}$ Ahmed AA. Monetary Stability and Economic Growth in Nigeria. Economic and Financial Review, Vol 27, No I, 1989. pp: 30-32

${ }^{52}$ Anyanwu JC. President Babangida's Structural Adjustment Programme and Inflation in Nigeria. Journal of Social Development in Africa, 7 (1), 1992, pp: 5-24.

${ }^{53}$ Anyanwu JC. External Debt Management Strategies under the Structural Adjustment Programme in Nigeria: Implications and Agenda for Action, paper presented at the Annual Conference of the Nigerian Economic Society, OAU, Ile Ife, 1988. pp: 3-7.

${ }^{54}$ Nwagbara EN. Industrial relations under structural adjustment programme: a comparative analysis of Nigeria and Ghana. (unpublished Ph. D dissertation submitted to the Graduate School, University of Calabar, Calabar) 2004.

${ }^{55}$ Obadan MI, Ekuehare BU. The Theoretical Bases of Structural Adjustment Programmes in Nigeria: An Appraisal. International Social Science Journal, Vol XII, No 2, 1989, pp: 211-222. 
crude collectors, and to energize industrialist gatherers in the economy. The rising structure of dependent private enterprise conceives just a strong part of the administration in a renovated economic condition of exceptionally diminished government ownership and control of rural and modern endeavours.

The particular purpose of the SAP includes:

- To rebuild and enhance the beneficial base of the economy with the aim of decreasing reliance on the oil sector and on imports,

- To accomplish fiscal and balance of payments reasonability over the period,

- To lay the foundation for a practical non-inflationary development,

- To lessen the strength of ineffective interest in the public sector, enhance the sector's effectiveness and improve the development capability of the private sector. ${ }^{56}$

The principal components of the Nigerian SAP are:

- The fortifying of demand administration strategies,

- The selection of measures to animate household creation and widen the supply base of the economy,

- The selection of a reasonable conversion scale policy through the foundation of a Second-level Foreign Exchange Market (SFEM),

- The legitimization and rebuilding of the levy administration to help the advancement of modern enhancement,

- Progressive trade and payments progression,

- The diminishment of complex organization controls and cultivating dependence on market powers,

- The reception of fitting estimating arrangements for public enterprise,

- The justification, commercialization, and privatization of public sector ventures. ${ }^{57}$

The center strategies of the SAP include measures to:

- Correct for the overvaluation of the naira through the setting up of a feasible SFEM, combined with changes in accordance with the official rate, and aimed for a union of the two rates as quickly as time permits overcome the observed public sector wasteful aspects through enhanced public consumption control programs and the legitimization of parastatals,

- Relieve the obligation load and draw in a net inflow of outside capital while keeping a cover on remote credits. ${ }^{58}$

Family Economic Advancement Programme was an economic policy of Late General Abacha's regime in 1997..59 It was built up

${ }^{56}$ Philips AO. A General Overview of Structural Adjustment Programme. Philips AC and Ndekwu E C (eds) Structural Adjustment Programme in a Developing Economy: The Case of Nigeria, NISER, Ibadan, 1987, pp: 1-12.

${ }^{57}$ Federal Government of Nigeria., Structural Adjustment Programme for Nigeria, July 1986-June 1988, Federal Government Printer, Lagos. 1986.

${ }^{58}$ Okongwu SP. Review and Appraisal of the Structural Adjustment Programme. Business Times, Lagos, September 28. 1987.

${ }^{59}$ Bamgboye PO. The Military and Socio-Economic Development in Nigeria (19831999) A Critical Appraisal. Mediterranean Journal of Social Sciences, 2014. p: 2342. to enable Nigerian families for economic independence and social integration. Potential business people and privately based makers of products and ventures were to profit from the program. The root for the mechanical take off of the country was being laid by FEAP using indigenous abilities plants and in addition apparatus and equipment made in Nigeria. As a strengthening program, FEAP tries to advance feasible agro and none agro-based undertakings in the neighbourhood government territories of Nigeria. It points additionally to dispatch activities and accelerate private division inclusion in economic improvement.

The primary target of FEAP, as indicated by the government in the 1997 yearly spending plan, was to outfit the assets that exist in the country regions with a view to building up suitable house ventures and different undertakings that will guarantee the much wanted economic strengthening of the rural masses. ${ }^{60}$

General Abdulsalami Abubakar assumed control over the mantle of authority on the 9th of June, 1998, at the demise of General Sani Abacha. His primary concentration was to sort out a quiet change of administration to a democratic system of government which he eventually accomplished in the year 1999 when Retired General Olusegun Obasanjo assumed control as the duly elected president of the federal republic of Nigeria in May 1999.

\section{Conclusion}

The economic impacts of military rules were disastrous, despite the fact that we can't refuse to credit them for some of their formative economic arrangements which helped the country eventually in time; most particularly, Muritala/Obasanjo. Nigeria's traditional agricultural based economy was deserted and the country turned out to a very large extent an exporter of crude oil, which because of incessant vacillations in oil costs prompted an unsteady economy. The Babangida administration was noted for "net ineptitude and unbridled, waste and bungle, the privatization of public office and public assets, the disregard of non-oil sectors and misplaced priorities. Basically, the emphasis was on the private sector instead of the benefit of the country. Yakubu Gowon was faced with the civil war and post civil war efforts while Muritala/Obasanjo regime did a very great job in stabilizing the economic condition of the country, even though they enjoyed the abundance of crude oil money during their regime. Buhari/ Idiagbon's regime did more of damage control for the economy by cutting cost and reducing administrative corruption among the civil service. Babangida's regime adopted the austerity measure of Buhari/ Idiagbon's regime but was also characterized by huge corrupt practices which further damaged the economy of the country. Abacha helped build domestic businesses while Abdusalam's regime handed over power to a democratically elected government in 1999. Due to the military-economic approach of the 1980 s, $45 \%$ of foreign-exchange profits were venturing into the debt servicing and there was almost no development. ${ }^{61}$ This prompted an ascent in destitution, wrongdoing, child abuse, illness, institutional rot and urban disengagement. The insecurity and disappointment caused by these arrangements were one of the reasons for the frequent pattern of a coup.

${ }^{60}$ Obinne CP. The Family Economic Advancement Programme in Nigeria: A Rural Development Approach. Community Development Journal, Vol. 34, no. 3, 1999 pp: 252-254.

${ }^{61}$ Abdulwaheed SA, et al. Dynamics of Government Policies in Nigeria's Economic Development (1960-1979). Journal of Economics and Sustainable Development www.iiste.org ISSN 2222-1700 (Paper) ISSN 2222-2855 (Online) Vol.3, No.11, 2012. 